\title{
Hivatali diszkrimináció? Egy online terepkísérlet eredményei ${ }^{1}$
}

\author{
Csomor Gábor² - Simonovits Bori - Németh Renáta4 ${ }^{4}$ \\ https://doi.org/10.51624/SzocSzemle.2021.1.1 \\ Beérkezés: 2020. 12. 07. \\ Átdolgozott változat beérkezése: 2021. 03. 09. \\ Elfogadás: 2021. 03. 20.
}

\begin{abstract}
Összefoglaló: 2020 elején a magyarországi helyi önkormányzati hivatalok körében kontrollált terepkísérletet végeztünk annak céljából, hogy feltárjuk az online ügyintézés során esetlegesen elöforduló hivatali diszkrimináció nyilt és burkolt formáit. Összesen 1270 e-mailben egy hétköznapi ügyintézéssel kapcsolatban fogalmaztunk meg egyszerú kérdéseket magas és alacsony státuszú roma és nem roma ügyfelek „bőrébe bújva”. A nemzetközi eredményekkel összhangban a válaszok arányában nem, de a válaszok tartalmi jellemzőiben jelentősebb eltéréseket találtunk az elsődleges kísérleti változó, az etnicitás mentén. A másodlagos kísérleti változóként bevezetett társadalmi státusz mutató hatása ugyanakkor mind a válaszok arányában, mind a többi tartalmi indikátor mentén statisztikailag igazolódott. A válasz-e-mailek gépi tanulásra épülő elemzése is alátámasztotta, hogy a közhivatalnokok különbséget tesznek ügyfeleik vélt státusza szerint, míg a vélt etnicitás vonatkozásában jóval kisebb fokú ez a különbségtétel. Összehasonlítva az etnicitás és a státusz hatását, fontos hangsúlyozni, hogy az etnicitás mentén a válaszok nyelvi megformálását tekintve csak árnyalatnyi különbség látszott; ugyanakkor a státusz szerinti különbségtétel a figyelmen kívül hagyásban is érvényesült, és nyelvileg is explicitebb módon jelent meg, ezért ennek hatása világosan detektálható volt a gépi szövegelemzés segítségével is. Összhangban Bartoš és szerzőtársai (2016) által a bérlakáspiacon megjelenő figyelemdiszkriminációként leírt jelenséggel, az önkormányzati ügyintézés során is azonosítottuk tehát az alacsony státuszú kísérleti személyek kérdéseinek gyengébb minőségú megválaszolását.
\end{abstract}

Kulcsszavak: terepkísérlet, diszkrimináció, roma, társadalmi státusz, önkormányzatok

\section{Bevezetés}

Magyarországon (és a régióban) az etnikai alapú diszkrimináció mindennapos gyakorlat, akár civil, akár kormányzati, akár EU-s jogvédő szervezetek jelentéseiből (el-

1 A szerzők köszönettel tartoznak a kéziratot elbíráló anonim lektoroknak és a TASZ munkatársainak (kiemelten Szabó Máté Dánielnek és Szabó Attilának), akik jogi állásfoglalásukkal és tanácsaikkal segítették a munkánkat. Továbbá Bolnovszky Balázsnak, Csillag Mártonnak, Farkas Dalmának, Rakovics Mártonnak és Simonovits Gábornak, akik a kutatás különböző szakaszaiban segítették megvalósulását.

2 Eötvös Loránd Tudományegyetem, Társadalomtudományi Kar, email:gaborcsomorstats@gmail.com. A szerzőt az Új Nemzeti Kiválóság Program pályázat támogatta kutatási munkájában.

3 Eötvös Loránd Tudományegyetem, Pedagógiai és Pszichológiai Kar, Interkulturális Pszichológiai és Pedagógiai Intézet, email:simonovits.borbala@ppk.elte.hu. A szerzőt a „Diszkrimináció és bizalom a közösségi gazdaságban” című NKFIH FK 12798 sz. kutatási projekt támogatta kutatási munkájában.

4 Eötvös Loránd Tudományegyetem, Társadalomtudományi Kar, Research Center for Computational Social Science, email:nemeth. renata@tatk.elte.hu. A szerzőt a K-134428 azonosítójú NKFIH pályázat támogatta kutatási munkájában. 
sősorban Társaság a Szabadságjogokért, TASZ, ${ }^{5}$ illetve Egyenlő Bánásmód Hatóság, EBH jogesetei, ${ }^{6}$ European Roma Rights Center, ERRC 20207), akár kutatási eredményekből indulunk ki. Számos empirikus kutatás foglalkozott a különböző kisebbségek, ezen belül is a romák diszkriminációjának vizsgálatával az Európai Unióban (például ERRC 2007, EU MIDIS I., II., European Commission 2019) és Magyarországon egyaránt (Neményi-Ságvári-Tardos 2013, 2019). Ezen kutatások egy része a terepkísérlet módszerére épült, melynek előnye, hogy - megfelelő kutatási dizájn megvalósítása mellett - nagyfokú belső érvényességgel rendelkezik. A romákkal szembeni diszkriminációt mérő számos terepkísérlet valósult már meg a magyar munkaerőpiacon (Hidas-Machlica-Žúdel 2014: 20-21, Pálosi-Sik-Simonovits 2007, Sik-Simonovits 2008). A büntetőeljárásban, illetve rendőrségi igazoltatási gyakorlatban megjelenő diszkriminációt magyar adatokon többek között a Magyar Helsinki Bizottság (KádárKörner-Moldova-Tóth 2008, Bárdits et al. 2014), illetve Miller és szerzőtársai vizsgálták (2008) az elmúlt időszakban. A közszolgáltatásokhoz való hozzáférés területén megjelenő etnikai diszkrimináció feltérképezésére azonban - legjobb tudomásunk szerint - Magyarországon mind ez idáig nem történt tudományos célú kísérlet, ezért jelen tanulmány célja e hiányosság pótlása. Kutatásunk kiinduló kérdése az volt, hogy vajon az önkormányzati hivatalokban dolgozó közalkalmazottak és köztisztviselők körében hasonló módon elterjedt-e a romákkal szembeni hátrányos megkülönböztetés gyakorlata, mint ahogyan azt a magánszféra, illetve a büntetőeljárás szereplői esetében tapasztalták korábbi empirikus kutatások.

Úgy véljük, kutatássorozatunk policy relevanciája is jelentős. Az EU tagállamai, beleértve Magyarországot, jelentős összegeket költenek romákkal kapcsolatos kutatásokra, inklúziós projektekre és azok monitorozására. S bár a monitorozó jelentések tagadhatatlanul kulcsfontosságú részei a tényalapú policyalkotásnak, fontos hiányosságuk azonban, hogy a roma diszkrimináció konkrét mértékéről nagyon kevés derül ki belőlük. ${ }^{8}$ Kutatássorozatunk ezt a hiányosságot is pótolni igyekezett.

2020 februárjában a magyarországi helyi önkormányzatok körében vizsgáltuk a hivatalnokok romákkal szembeni hátrányos megkülönböztetését egy online terepkísérlet keretében ( $\mathrm{N}=1270)$. A kísérlet során e-maileket küldtünk az önkormányzatok hivatalos elérhetőségére, melyekben egy hétköznapi ügyintézéssel kapcsolatban fogalmaztunk meg egyszerü kérdéseket: a roma és nem roma hangzású néven kiküldött

\footnotetext{
TASZ-esetek: https://tasz.hu/temaink/audience/romak?q=diszkrimináció\&search=Keresés\#

EBH-esetek: https://www.egyenlobanasmod.hu/hu/jogeset vagy https://www.egyenlobanasmod.hu/hu/kereses?search_api_fulltext=roma ERRC: http://www.errc.org/press-releases/romani-families-win-appeal-against-paris-municipality-over-school-segregation

8 Azegyikjelentős romainklúziósmonitoringeszköza Roma Civil MonitorProject, amely négy kulcsterületen:afoglalkoztatás, lakhatás, egészségügyésoktatás területénmérifelaroma integrációelőrehaladását(AlegutolsójelentéssorozataCentrefor PolicyStudiesoldalánérhetőel[2018]). A Civil Monitor hasznos és hiteles forrás abból a szempontból, hogy katalógusszerüen összefoglalja a tagországok romaintegrációval kapcsolatos intézkedéseit, azonban sokszor csak anekdotikus bizonyítékok alapján értékeli az előrehaladás mértékét (azaz kevés kemény indikátort tartalmaz). Másik jelentős forrásként említhető az FRA által végzett EU MIDIS Survey, amely kvantitatív módszerekkel méri az európai kisebbségek, beleértve a romák diszkriminációs tapasztalatait is (2016). S bár a survey-módszerekkel gyūjtött adatok jól összehasonlíthatóak az egyes tagországokban, mégis számos „total surveyerror"-ral kapcsolatos kérdéstfelvetnek (ideértvea lefedettséget, a nemválaszadást, azemlékezés problémáját és a kérdezőbiztos torzító hatását), amelyek nem elhanyagolhatóak egy olyan érzékeny téma vizsgálatánál, mint a diszkrimináció.
} 
e-mailekben érdeklődtünk lakókocsi számára alkalmas parkolóhelyről. ${ }^{9}$ (Az e-mailszövegek és kérdések pontos megfogalmazást a melléklet tartalmazza.)

A tanulmány a következőképpen épül fel: a bevezető fejezetet követően a második fejezet áttekintést nyújt az általunk használt diszkriminációfogalom elméleti keretéről, a közhivatalok etnikai kisebbségekkel szembeni diszkriminációját vizsgáló korábbi kutatások módszertanáról és eredményeiről. A harmadik fejezet ismerteti a kutatás módszerét, a kísérleti dizájnt és a hipotéziseket. A negyedik fejezet az eredményeket mutatja be: előbb a tesztelés deskriptív eredményeit, majd pedig a hatásmérést. $\mathrm{Az}$ ötödik fejezetben összefoglaljuk és megvitatjuk a kutatás legfontosabb eredményeit.

\section{Elméleti és módszertani háttér}

\subsection{Elméleti és jogi keret}

A diszkriminációt, azaz a hátrányos megkülönböztetést a legegyszerübben a következő definícióval ragadhatjuk meg: egy csoport tagjai eltérő bánásmódban részesülnek - munkaerőpiaci helyzetben például a felvétel, bérezés vagy előléptetés során -, mint egy másik csoport tagjai, és ennek a megkülönböztetésnek valamely csoporthoz tartozásuk (például nemük, életkoruk, etnikai hovatartozásuk) az alapja (Phelps 1972, Arrow 1998, Loury 2006).

Amennyiben egy adott országban létezik diszkriminációellenes szabályozás, akkor a hátrányos megkülönböztetés legegyszerübben ezen szabályok semmibevételeként fogható fel. Magyarországon 2004-ben lépett hatályba a 2003-as Ebktv., ${ }^{10}$ mely rendelkezik a mindennapi élet különböző szféráiban - többek között a közszolgáltatásokhoz való hozzáférés területén is - az egyenlő bánásmód megvalósításának szabályozásáról. A jogszabályok különbséget tesznek a diszkrimináció különböző megjelenési formái közül, melyek közül kutatásunk szempontjából legfontosabb a közvetlen (azaz nyíltan megnyilvánuló) és a közvetett (látszólag semleges intézkedés, melynek során valamely kisebbség tagjai hátrányt szenvednek) forma.

Szociológiai szempontból a diszkrimináció nyílt (overt) és burkolt (subtle, covert), esetleg látens (latent) formáit szokás megkülönböztetni (Pager-Shepherd 2008). Mivel a modern társadalmakban a diszkrimináció tilalma jogilag meghatározott, és egyre nagyobb jogtudatosság van a társadalmakban ezzel kapcsolatban, módszertani szempontból kulcskérdés, hogyan mérhetők a diszkrimináció burkolt formái. Nyilvánvalóan minden módszernek megvannak a maga hiányosságai és erősségei (külső és belső validitás szempontjából), és az sem mindegy, hogy a diszkrimináció mely aspektusát

9 Az előkutatás során többféle szituáció tesztelése felmerült bennünk. Végül abból a pragmatikus megfontolásból esett a " „lakókocsis kérdésre" a választásunk, mert ebben a témában sikerült a legtöbb, egy levélen belül felteendő kérdést megfogalmaznunk, és ezt a szempontot a diszkrimináció finomabb mérésének szempontjából fontosnak tartottuk.

10 2003. évi CXXV. törvény, az egyenlő bánásmódról és az esélyegyenlőség előmozdításáról: https://net.jogtar.hu/ jogszabaly?docid=a0300125.tv 
(többség vagy kisebbség percepciója) és kinek a szempontját célozzuk megragadni (elkövető vagy áldozat). (Minderről lásd részletesebben Koltai-Sik-Simonovits 2015).

Kutatásunk szempontjából érdemes röviden bemutatni a figyelem-diszkrimináció elméleti modelljét (attention discrimination Bartoš et al. 2016), melynek segítségével a diszkrimináció burkolt formái is jól megragadhatók. A Bartošék által a bérlakáspiacon megfigyelt jelenség lényege ugyanis, hogy a döntéshozó eltérő mértékű figyelmet szentel a többségi és kisebbségi jelentkezőnek. Bartoš és munkatársai a német- és csehországi magánbérlakás-piacon tanulmányozták a kisebbségekkel szemben megfigyelhető diszkriminatív tulajdonosi viselkedést, és jelentős különbséget találtak a többségi (cseh, illetve német) és a kisebbségi (roma és ázsiai) tesztelők számára elérhető lakások arányában és az ügyfelek tájékoztatásának minőségében is. Terminológiai újításuk, hogy modelljükben összekapcsolták az elégtelen figyelem és a diszkrimináció jelenségét. A folyamat lényege, hogy a kisebbség és többség iránt tanúsított figyelem eltérő mértéke eredményezi az információhoz való hozzáférésben bekövetkező aszimmetriát. Más szóval, míg a többségi tesztelő nagy eséllyel széles körű tájékoztatást kap döntéshozótól, addig a kisebbségi tesztelő inkább hevenyészett, hiányos tájékoztatásban részesül. Ez a fajta különbség az önkormányzati tájékoztatás minőségében is jól modellezhető, amennyiben olyan komplex kérdést fogalmazunk meg, melyre részletes választ várunk el (lásd lakókocsis kirándulással kapcsolatos kérdéseinket a mellékletben).

Mivel az etnicitás mellett a státuszhatást is beemeltük kísérleti változóként, érdemesnek tartjuk röviden bemutatni a diszkriminációval foglalkozó közgazdasági megközelítések két alapvető csoportját: az ízlésalapú és a statisztikai diszkriminációs modelleket. Az ízlésalapú diszkrimináció Becker-féle alapmodelljének (Becker 1971) kiindulópontja, hogy a munkaerőpiac többségi résztvevői nem kívánnak a kisebbséghez tartozókkal együtt dolgozni, előítéletes egyéni preferenciáik miatt. A diszkrimináció másik alapmodellje a statisztikai diszkrimináció modellje (Phelps 1972, Arrow 1973), mely szerint a munkaadó keresi a módját annak, hogy a munkavállaló hatékonyságát megismerje. Mivel erre nincs mód, inkább közvetett jelzésekre alapozza döntését, mint például iskolai végzettség, felvételi teszt, személyes kapcsolatokban megtestesülő ajánlás vagy a munkavállaló látható jellegzetessége is (faji és etnikai hovatartozás, nem, életkor). A statisztikai diszkrimináció az ízlésalapúval szemben tehát nem a munkáltató preferenciái, hanem az információs aszimmetria miatt alakul ki; a modell szerint ugyanis a munkáltató a teljes információ birtokában nem diszkriminálna. Tehát a statisztikai diszkrimináció annyiban „kedvezőbb” az ízlésalapú diszkriminációnál, hogy a munkáltatónak nincs kifogása az adott kisebbséggel szemben, csupán a várható költséget akarja minimalizálni (Lovász-Telegdy 2009), és ebből következően az előbbi könnyebben megváltoztatható tapasztalatok alapján, mint az utóbbi.

Azt, hogy a gyakorlatban melyik típusú diszkrimináció érvényesül, általában nehéz eldönteni, de kontrollált kísérleti elrendezéssel viszonylag könnyen modellezhető: erre számos munkaerőpiaci (Kaas-Manger 2010, Weichselbaumer 2016 munkáit), illetve különböző szolgáltatásokhoz való hozzáférést tesztelő empirikus példát talá- 
lunk a szakirodalomban (lásd például Gneezy-Price-List 2012, illetve Cui-Li-Zhang 2017). Kérdéses azonban, hogy az önkormányzati ügyintézők tesztelése során hogyan operacionalizálható az a „plusz információ”, amelyet a munkaerőpiaci tesztelések során a jelentkezéshez csatolt referencialevél vagy egy jobban megírt, több információt tartalmazó önéletrajz jelenít meg. Jelen kutatás során az igénylő társadalmi státuszának (alacsony vs. magas státusz) manipulálásával kerestük a választ erre a kérdésre. Ha ugyanis nem a roma származás, hanem a valóságban ezzel erősen korreláló alacsony státusz áll a diszkrimináció mögött (mert például az ügyintéző azt feltételezi, hogy nagyobb munkaidő-ráfordítással jár az alacsony státuszú ügyfél tájékoztatása és segítése, és ez lenne a statisztikai diszkrimináció), akkor a státusz és az etnicitás együttes megjelenítése és a levelek közötti egyenletes elosztása tisztázná ezt a relációt. Persze emellett az is előfordulhat, hogy az ügyintéző előítéletes ízlésbeli preferenciái az alacsony státuszúakra is (vagy csak az alacsony státuszú romákra) vonatkoznak, tehát nem kizárólag statisztikai alapon diszkriminálja az alacsony státuszú ügyfeleket, hanem ízlésalapon is.

\subsection{A diszkrimináció mérése kontrollált kísérlettel}

A diszkrimináció mérésének számos módja terjedt el a társadalomtudományokban (survey-k, statisztikai adatgyưjtés, kvalitatív interjúk, kísérletek és megfigyelés), melyek eltérő validitási problémákat vetnek fel. A kontrollált terepkísérlet módszere sok szempontból a legalkalmasabb a diszkrimináció mérésére.

A randomizált kontrollált kísérlet olyan kísérlet, ahol a kísérleti alanyokat véletlenszerűen sorsolják kezelési csoportokba. Ha megvalósul a véletlenszerű elrendezés - esetünkben az e-mailek egyik felét roma, a másik felét pedig nem roma hangzású névvel írjuk alá -, akkor lehetőségünk van a kezelés kimenetre gyakorolt ún. átlagos kezelési hatását mérni, hiszen a randomizáció miatt elvileg semelyik más változó nem függhet össze a kezeléssel (Valli-Stahl-Feit 2017: 8). Ezért a kutató nem csupán az együtt járásra vonatkozó leíró jellegû megállapítást tehet (mint a klasszikus survey és más megfigyeléses vizsgálatok esetén), hanem oksági kapcsolatot is igazolhat a vizsgált változók között. Éppen ezért a randomizált kísérletek belső validitása magas (hiszen az eredmények lehetőséget adnak az oksági kapcsolat feltárására), és megfelelő mintavételi módszer kialakítása esetén magas szintű külső validitás is megvalósítható (mivel az eredmények az alapsokaságra is általánosíthatók).

Azt a feltételezésünket, hogy a diszkrimináció mérésére irányuló kontrollált terepkísérletek nemzetközi szinten is viszonylag új kutatási módszernek tekinthetőek a közszféra területén, az alábbi módon teszteltük. A szakirodalom-gyüjtés fázisában a következő kulcsszavakat használva a Google Tudóson: „field experiment” AND discrimination AND ('public sector' OR 'public services') mindössze nyolc publikációt találtunk, melyek kísérleti alanyai a helyi vagy központi kormányzat alkalmazásában álló hivatalnokok voltak, és amelyek online ügyfélszolgálati diszkriminációt vizsgáltak. Ezek a kutatások, mint azt a melléklet M1. táblázata mutatja, mind az elmúlt hét 
évben születtek és - egy kínai kutatást leszámítva - jellemzően Nyugat-Európában vagy az Egyesült Államokban valósultak meg.

A korábbi kutatások módszertanában közös, hogy egyrészt véletlenszerűen sorolták csoportokba a hivatalokat, másrészt valamilyen hétköznapi kérdést küldtek el kisebbségi és többségi hangzású névvel aláírva. A diszkrimináció mértékét kvantitatív (elsősorban a válaszok kisebbségi/többségi csoportok szerinti gyakorisága) és kvalitatív eszközökkel (segítőkészség, információtartalom) határozták meg. A kísérletek leginkább abban különböztek egymástól, hogy milyen területen (óvodai férőhellyel, munkanélküli-segéllyel vagy parkolóhellyel kapcsolatos információkérés) vizsgálták a diszkrimináció megjelenését, valamint hogy emberi kódolókat (Adman-Jansson 2017) vagy számítógépes algoritmusokat (Giulietti-Tonin-Vlassopoulos 2015) alkalmaztak a válaszok kiértékelésére. Az utóbbi alkalmazása drasztikusan csökkenti a kutatás költségeit, és lehetővé teszi a mintavételre épülő teszteléssel szemben a teljes sokaság lekérdezését. Ugyanakkor Giulietti és társai (az egyetlen számítógépes szövegfeldolgozást használó kutatás) hiányosságaként megemlítendő, hogy a válaszidő és a szavak (gyorsabb, pontosabb) számolásán túl tartalmilag nem nyújtott bővebb elemzést a diszkrimináció különböző lehetséges formáiról, szemben az emberi (kvalitatív) értékeléseket alkalmazó kutatásokkal (például jött-e válasz, válaszidő, köszönés és tiszteletteljes megszólítás).

Az egyik kihívás, amivel a kutatóknak meg kell birkózniuk, a megfelelő mintavételi keret, azaz egy érvényes címlista összeállítása. Például a már említett amerikai kutatásban Giulietti és társai (2015) fehér és fekete hangzású nevekkel ellátott e-maileket küldtek ki több mint 19 ezer megyei és helyi közszolgáltatónak. A címzettek listája meglehetősen változatos hivatalos szerveket tartalmazott (például iskolai kerületeket, helyi könyvtárakat, jegyzőket, seriff-, adó- és munkaügyi hivatalokat). Ugyanakkor a nagy mintaelemszám ellenére a kutatók csak azokat a szolgáltatókat tudták bevonni a kutatásba, melyek e-mail-címe egy helyen volt összegyújtve, és nyilvánosan elérhető volt. Amennyiben egy ország megyei és helyi közszolgáltatói maguk döntenek arról, hogy közzéteszik-e az e-mail-címüket, akkor még az ilyen nagymintás kutatások esetén, mint amilyen Giulietti és szerzőtársaié is volt, kérdéses az eredmények általánosíthatósága (self-selection bias).

\subsection{Korábbi kutatási eredmények}

Az általunk vizsgált korábbi kutatások szinte egybehangzó tanulsága, hogy a diszkrimináció jellemzően nem a hivatalnokok válaszolási hajlandóságának mértékében érhető tetten, hanem sokkal inkább a kapott válaszok minőségi eltéréseiben. Ennek oka egyszerúen az, hogy a modern nyugati világban a diszkrimináció tilalma jogilag szigorúan meghatározott, és az önkormányzati tisztviselők mint közhivatalnokok feltehetőleg teljes mértékben tisztában vannak az országukban hatályos jogi szabályozással. Ezért a nyílt diszkriminációs formák nem jelennek meg. Emellett az ügyfelek teljes 
mértékủ ignoranciája sem jellemző azokban az államokban, ahol hivatali kötelezettség válaszolni az írásos kérdést megfogalmazó ügyfélnek.

Mindössze két, sok szempontból sajátos ${ }^{11}$ tanulmányban találtak jelentős különbséget a válaszarányokban. Az egyik egy kínai kísérlet volt, ahol jelentős (15 százalékpontos) különbséget mértek a szerzők a muszlim és kínai hangzású nevekkel ellátott e-mailek között (Distelhorst-Hou 2014). A másik pedig a már említett amerikai kutatás volt, ahol kicsi (mindössze 4 százalékpontos) különbséget figyeltek meg a kutatók a fekete és fehér hangzású nevű felhasználók postafiókjaiba beérkezett válaszarányok között (Giulietti-Tonin-Vlassopoulos 2015). Érdemes megemlíteni továbbá, hogy a nyugati demokratikus országokban több más kutatás is Giulietti és szerzőtársaihoz hasonló mértékủ hatást mért válaszarány tekintetében, ezek a különbségek azonban az alacsony elemszámú minta miatt statisztikailag nem voltak szignifikánsak.

Mindazonáltal, az összes általunk szemlézett kutatás szerzői megfigyelték a diszkriminációnak valamiféle finomabb megnyilvánulását, ami a hivatalnokok által küldött válaszok tartalmában vagy hangnemében nyilvánult meg. Németországban azt találták, hogy a feltételekhez kötött pénzbeli ellátások igénylésének menetét a hivatalnokok nehezebbnek állították be a nem német érdeklődők, mint a németek számára (Hemker-Rink, 2017). Hasonlóképpen, Belgiumban azt figyelték meg, hogy a magrebi nevú érdeklődők hiányosabb információt kaptak a magánfenntartású idősotthonok múködéséről és a felvételi eljárás módjáról, mint a flamand nevú érdeklődők (Jilke-Van Dooren-Rys 2018). Az összes általunk vizsgált kutatásban a szerzők különbséget találtak a hivatalnokok hangnemében, azaz abban a tekintetben, hogy mennyire voltak kedvesek, segítőkészek a kisebbségi és többségi csoportokkal szemben. A kedvességet rendszerint objektív kritériumok alapján a köszönési formák és címzett néven szólításának gyakoriságával mérték a kutatók. Hemker és Rink (2017) megkísérelte szubjektív módon is értékelni a válaszokat, mégpedig úgy, hogy a szerzőpáros egymástól függetlenül a saját benyomása alapján „kedvesnek” vagy „nem kedvesnek” kategorizálta a válaszadó hivatalnokokat. A két szerző értékelése azonban nagyban eltért egymástól, amiből arra lehet következtetni, hogy a hivatalnokok hangnemének konzisztens értékelése meglehetősen öszszetett és nagymértékben szubjektív feladat. Összességében mind az elméleti áttekintésből mind az empirikus szakirodalomból megállapítható, hogy a diszkrimináció sokdimenziós jelenség, amely nemcsak nyilt, hanem látens vagy burkolt formákban is megnyilvánulhat.

\section{Módszerek}

\subsection{Kutatási dizájn}

Jelen kutatás célja az volt, hogy e-mailben feltett kérdések segítségével teszteljük a romákkal szembeni diszkrimináció mértékét az önkormányzati hivatalok online ügyinté-

11 Az amerikai kutatás sajátossága az ország méretéből adódó óriásminta, míg a kínai kutatás sajátossága az antidemokratikus politikai berendezkedésből következő korlátok, nevezetesen, hogy sem megfelelő etikai jóváhagyás, sem a tudományos életben kulcsfontosságú valós kritika nem biztosított. 
zésében. A kontrollált kísérleti dizájn alapja az volt, hogy az összes önkormányzatnak ugyanazt az e-mail-szöveget küldtük ki, csupán az e-mail-címben szereplő felhasználónevét és az üzenet aláírását variáltuk, utalva az érdeklődő etnikai hátterére (roma vs. nem roma). Továbbá az etnicitás mellett bevezettünk egy másik, az etnicitástól függetlenül kiosztott társadalmi státusz változót is, melyet a szöveg tartalmi és stiláris jellemzőivel operacionalizáltunk: a kiküldött e-mail-szövegek fele nyelvtanilag és stilisztikailag helyesen volt megírva (magas státusz), másik fele pedig nyelvtani, helyesírási és stilisztikai hibákat tartalmazott (alacsony státusz). Összesen tehát négyfajta felhasználói profilt ( $2 \times 2$ elrendezésben) használtunk a kísérletben úgy, hogy az önkormányzatok mindegyike kizárólag egy-egy személytől kapott e-mailt, randomizált elrendezésben.

A kísérleti dizájnt az 1. táblázatban foglaltuk össze: A két dimenzió közül az etnicitás volt a kutatás elsődleges kísérleti változója, hiszen alapvetően arra voltunk kíváncsiak, hogy létezik-e a romák diszkriminációja az online hivatali ügyintézésben. A státusz dimenziót másodlagos kísérleti változóként vontuk be, a diszkrimináció finomabb múködési mechanizmusai megértésének céljából. A 2×2-es elrendezés, melyben a négy kísérleti profil mintabeli eloszlása egyenletes, lehetőséget adott arra, hogy az etnicitási hatást tisztán, a felhasználó társadalmi státuszától függetlenül tudjuk mérni, és vice versa: a státusz hatását az etnicitástól leválasztva tudtuk mérni.

1. táblázat: Kísérleti dizájn: státusz és etnicitás 2×2-es elrendezése ( $N=1269)$

\begin{tabular}{|c|c|c|}
\hline & \multicolumn{2}{|c|}{ etnicitás (roma és nem roma) } \\
\hline \multirow{2}{*}{$\begin{array}{c}\text { státusz (alacsony vs. } \\
\text { magas) }\end{array}$} & $\begin{array}{l}\text { alacsony státuszú roma } \\
\qquad(\mathrm{N}=316)\end{array}$ & $\begin{array}{l}\text { alacsony státuszú nem roma } \\
\qquad(\mathrm{N}=316)\end{array}$ \\
\hline & $\begin{array}{c}\text { magas státuszú roma } \\
(\mathrm{N}=318)\end{array}$ & $\begin{array}{l}\text { magas státuszú nem roma } \\
\qquad(\mathrm{N}=319)\end{array}$ \\
\hline
\end{tabular}

Jelen kutatás hipotéziseit korábbi empirikus eredményekre alapozva a következőkben foglalhatjuk össze:

Elsődleges hipotézisek:

H1: A roma hangzású névvel rendelkező felhasználók kisebb eséllyel kapnak választ a hivataltól.

Az önkormányzati diszkrimináció során érvényesül a romákkal szembeni figyelemdiszkrimináció, melynek értelmében:

H2: A roma hangzású névvel rendelkező felhasználók kisebb eséllyel kapnak teljes (informatív) választ a hivataltól.

H3: A roma hangzású névvel rendelkező felhasználók kisebb eséllyel kapnak kedves választ a hivataltól. 
Másodlagos hipotézisek:

H4: Az alacsonyabb státuszú felhasználók kisebb eséllyel kapnak választ a hivataltól. Az önkormányzati diszkrimináció során érvényesül az alacsony státuszúakkal szembeni figyelemdiszkrimináció, melynek értelmében:

H5: Az alacsonyabb státuszú felhasználók kisebb eséllyel kapnak teljes (informatív) választ a hivataltól.

H6: Az alacsonyabb státuszú felhasználók kisebb eséllyel kapnak kedves választ a hivataltól.

H7: Végül a státusz és etnicitás együttes hatása: statisztikai vagy ízlésalapú diszkrimináció: az igénylő társadalmi státuszának (alacsony vs. magas státusz) manipulálásával kerestük a választ arra kérdésre, hogy a romákkal szemben az ízlés- vagy a statisztikai diszkrimináció a jellemzőbb. Hipotézisünk szerint a magasabb társadalmi státuszú (azaz precízebben és helyesírási hibáktól mentesen megírt) roma aláírású e-mailekre nagyobb arányban érkeznek válaszok, mint az alacsony státuszú romák esetében, azaz a hivatali diszkrimináció inkább statisztikai. Ugyanakkor az alacsonyabb státuszú nem romák esetében a romákhoz képest magasabb válaszarányra számítunk, tehát az etnicitásnak megmarad az önálló hatása is.

\subsection{Minta meghatározása}

Az adatfelvétel idején (2020. február) Magyarországon összesen 3178 önkormányzat létezett, ezek nagy része több kistelepülést összefogó ún. közös önkormányzati hivatal keretében múködött, több kirendeltséggel (lásd „A mintakeret meghatározása” című fejezetet a mellékletben). Mivel fontosnak tartottuk, hogy a hivatalnokok egymástól függetlenül válaszolják meg az e-maileket, és lehetőleg minél kisebb eséllyel beszéljenek a kutatásunkról egymás között, a közös önkormányzati hivatalok egyetlen, véletlenül sorsolt kirendeltségét vontuk be a kutatásba. A 22 budapesti kerületből 12-t választottunk be; a főváros és a belső kerületek azért maradtak ki, mert a kutatás témája - lakókocsis parkolóhellyel és kempinggel kapcsolatos információszolgáltatás - nem tűnt életszerűnek az esetükben, illetve nem a fővárosi polgármesteri hivatal kompetenciájába tartozott. A tervezett mintakeretet így 1272 hivatal alkotta. A helyi önkormányzati hivatalok elérhetőségének összegyüjtésekor a 2015-ös Önkormányzati címtárból indultunk ki, az önkormányzatok honlapján ellenőrizve annak aktualitását. A mintakeretet végül a két bináris kísérleti változónak megfelelően négy megközelítőleg egyforma részre osztottuk véletlen módon. A mintakeret és a címlista meghatározásának, illetve a mintakeret felosztásának részletes leírása a mellékletben található.

Mivel randomizált módon történt a települések négy csoportba sorolása, várhatóan nincsen különbség azok között. Ugyanakkor ez csak nagy valószínűséggel, „várhatóan" igaz, ezért a besorolás után homogenitásvizsgálatot végeztünk, ahol azt ellenőriztük, hogy valóban sikeres volt-e az önkormányzatok véletlenszerű csoportba 
sorolása. Három települési jellemzőt vizsgáltunk: az önkormányzati hivatal típusát (önálló, nem önálló közös kirendeltséggel stb.), azt, hogy van-e a településen roma nemzetiségi önkormányzat, és a település típusát (község, nagyközség stb.). Egyik jellemző mentén sem tapasztaltunk statisztikailag bizonyítható eltérést a kísérleti csoportokon belüli eloszlást tekintve.

\subsection{Az üzenet tartalmának kiválasztási szempontjai}

Az üzenet tartalmának kialakítása során az egyik legfontosabb szempont a hitelesség volt. Ez alatt azt értjük, hogy úgy terveztük meg a kísérletet, hogy minél életszerübb legyen, és ne „lepleződjünk le”, mert az lehetetlenné tette volna, hogy természetes közegben figyeljük meg a reakciókat, illetve veszélyeztette volna a kísérlet sikeres megvalósítását. Az e-mail témájának meghatározásához interjús előkutatást végeztünk, melynek során több szakértővel és önkormányzati ügyintézővel beszéltünk (erről részletesebben lásd a mellékletet). Több szempont mérlegelése után úgy döntöttünk, levelünkben lakókocsi számára alkalmas parkolóhelyről fogunk érdeklődni. ${ }^{12}$

Azért, hogy a válasz várhatóan elég hosszú legyen ahhoz, hogy a válaszlevelek informativitása és kedvessége értékelhető legyen, azaz a diszkrimináció finomabb formái is tetten érhetőek legyenek, az érdeklődő e-mailünkben nem szorítkoztunk csupán a parkolóhelyre vonatkozó kérdésre, hanem utazásunkkal kapcsolatos további kérdéseket is feltettünk (kértük, hogy ajánljanak látnivalót a környéken, illetve további információforrást ezzel kapcsolatban). ${ }^{13}$ A mellékletben közöljük az e-mail teljes szövegét, két verzióban; a másodikban szándékos nyelvtani és stilisztikai hibákat vétve egy alacsony státuszú (hozzávetőlegesen nyolc általánost végzett) felhasználó írásmódját imitáltuk. Mindkét e-mailt roma és nem roma hangzású feladónévvel is kiküldtünk.

\subsection{Az e-mail-küldés megvalósitásának gyakorlati szempontjai}

A feladónév-választásnál jól beazonosítható roma, illetve nem roma nevek választására törekedtünk. A roma nevet egy korábbi kutatás alapján választottuk (Daróczi et al. 2017), amelyben a szerzők egy kényelmi mintán letesztelték a nevek „romaságát”. A semleges nevet pedig online elérhető család- és utónév-statisztikákból választottuk (Magyar Keresztnevek Tára é. n., Születési családnevek 2019). Mindkét névhez Gmailfiókot hoztunk létre, és a felhasználónév-kialakítással is utaltunk az e-mail küldőjének társadalmi státuszára. A kutatásban szereplő fiktív személyek nevét és e-mail-címét a 2. táblázatban foglaltuk össze.

12 A lakókocsis kérdést Grohs és társai kutatásából kölcsönöztük (2016).

13 Az összetettség mellett ugyanakkor fontos szempont volt az is, hogy ne terheljük jobban a hivatalnokokat a kérdésünkkel, mint amire a diszkrimináció méréséhez feltétlenül szükség volt. 
2. táblázat: Feladónevek és e-mail-címeik

\begin{tabular}{c|c|c} 
státusz & név & e-mail-cím \\
\hline alacsony & Kolompár Richárd & mr.kolompar.richard@gmail.com \\
\hline magas & Kolompár Richárd & kolompar.richard90@gmail.com \\
\hline alacsony & Nagy Péter & petikeanagy@gmail.com \\
\hline magas & Nagy Péter & nagy.83.peter@gmail.com
\end{tabular}

\section{A címzett kiválasztása}

A címzett kiválasztása szempontjából fontos volt, hogy olyan e-mail-címre küldjük az üzenetet, amellyel feltételezhetően minden önkormányzati hivatal rendelkezik, és ezt nyilvánosan közzé is teszi. Ilyennek bizonyult a központi kapcsolattartó e-mailcíme, és bizonyos értelemben ez is meghatározta a választható témák körét. Hiszen a választott témának kellően általánosnak kellett lennie ahhoz, hogy kis- és nagytelepülésen egyaránt meg tudja válaszolni az ügyintéző. A címzettek tehát az összes település esetében az önkormányzatok központi kapcsolattartói voltak. Más funkciójú hivatalnoknak (polgármester, jegyző) csak akkor címeztük az e-mailt, ha egyedül az ő e-mail-címe volt elérhető a település honlapján vagy az Önkormányzati címtárban, illetve ha a Gmail rendszere nem tudta kézbesíteni az ügyintézőnek az üzenetet.

Az e-mailek kézbesitése

A kézbesítést pilotkutatás előzte meg (lásd a mellékletben), a fő adatgyújtési szakasz 2020. február 26 és március 2. között valósult meg, egy informatikus által kifejlesztett Google API alkalmazás segítségével. A kézbesítetlen e-mailek esetén igyekeztünk alternatív elérhetőséget találni. A hivatalnokoknak csaknem két hetet hagytunk a válaszadásra (15 nap a közérdekű adatigénylés felső korlátja), a koronavírus-járvány magyarországi eszkalálódása miatt azonban március 15-én úgy döntöttünk, hogy lezárjuk az adatgyűjtést, és az ezután érkező e-maileket figyelmen kívül hagyjuk, hogy elkerüljük a rendkívüli helyzet okozta esetleges torzításokat.

Az e-mailek kézbesítése tervezésének és megvalósulásának részleletes leírása a mellékletben található.

\subsection{Adatfeldolgozás, kódolás, elemzési modellek}

A kezelés hatásának mérését regressziós modellekkel végeztük, ahol a függő változó szerepét a diszkriminációt mérő, a válasz-e-mailek kódolásával kapott többfajta indikátor töltötte be. A magyarázó oldalon két prediktor szerepelt: a (vélt) etnicitás (roma hangzású névvel rendelkező felhasználó) és a (vélt) társadalmi státusz (stílusában alacsonyabb státuszú szerzőre utaló levél). Egy második modellben az etnicitás és státusz interakcióját is vizsgáltuk. A függő változó típusától függően lineáris, bináris logisztikus vagy ordinális logisztikus regressziós modellt használtunk. 
A diszkriminációt mérő indikátorokat a válasz megtörténte (érkezett-e válasz a hivatalnak küldött e-mailre), illetve a választ jellemző tartalmi és stílusmutatók adták. Kódolási szempontrendszerünket a korábbi kutatások alapján alakítottuk ki. Válasznak minden olyan üzenetet elfogadtunk, amit a hivatalnok személyre szólóan írt, tehát nem automatikus válasz volt. Az egyetlen kivételt ez alól a továbbítás tényéről értesítő üzenetek képezték (például „Továbbítottam üzenetét a Polgármester Úrnak.”).

A parkolóhelyre vonatkozó érdeklődés kapcsán azt vizsgáltuk, hogy a hivatal válaszlevelében ajánlott-e parkolóhelyet a településen vagy annak környékén. ${ }^{14} \mathrm{~A}$ következő vizsgált tartalmi jellemző azt rögzítette, hogy a hivatal a levélíró kérését teljesítve ajánlott-e bármilyen látványosságot a településen vagy annak környékén. Az utolsó vizsgált tartalmi mutató a válasz teljességre vonatkozott. Ez a mutató azt rögzítette, hogy a hivatal ajánlott-e bármilyen forrást, ahol bővebb információ volt szerezhető a település történetéről.

A fenti indikátoroknak nem adtunk értéket, amennyiben a hivatalnok nem válaszolt a kérdésekre, de készségesnek mutatkozott (például telefonon vagy személyesen akarta megbeszélni). Információforrásnak bármilyen linket elfogadtunk, kivéve az olyan választ, hogy az érdeklődő nézzen körül az interneten vagy a Wikipédián.

A teljességen túl a válaszokat az önkormányzatot képviselő hivatalnok hangneme szerint három kategóriába soroltuk: (1) lekezelő, (2) semleges és (3) kedves. Egyes esetekben nehéz volt e szempont szerint értékelni a beérkező választ. Ez akkor fordult elő, ha a válaszadó (például jegyző) meglehetősen távolságtartó vagy bürokratikus nyelvezetet használt, de rendkívül részletesen válaszolt minden apró részletre. Ilyenkor a kedvesség helyett a segítőkészség használhatóbb szempontnak bizonyult. A hangnem egy objektívebb (bár csak proxy) indikátoraként megvizsgáltuk még az üzenetek hosszát is. Ezt azért tartottuk relevánsnak, mert a kódolás során az volt a benyomásunk, hogy a „kedves” választ író hivatalnokok üzenetei hosszabbak voltak, mint a „lekezelő” választ íróké, esetenként számos érdekes látnivalót és szabadidős tevékenységet soroltak fel a település környékén.

A válasz-e-mailek kódolását a kutatás egyik vezetője végezte el, előre rögzített szempontrendszer alapján (a szempontrendszerről bővebben lásd a mellékletet). ${ }^{15}$

A válasz-e-mail-szövegek kinyerése a fiókokból webscraping technikával történt. ${ }^{16}$ A módszertan további részletes leírása a mellékletben található.

14 A válasz informativitását mérő bináris változó értéke „0" lett, ha a hivatalnok elmondása szerint nem volt a településen lakókocsi számára kijelölt parkolóhely, és nem is ajánlott semmilyen más megoldást. A településen és annak környékén is elfogadtunk bármilyen parkolási javaslatot, beleértve a kempingeket vagy informális megoldást (például valakinek a háza előtt).

15 Annak érdekében, hogy a kódolás objektivitását megítélhessük, ugyanezen szempontrendszer alapján egy független kódolást is elvégzett egy kutatási asszisztens. A két kódolás közötti megfelelés (inter-coder reliability) alapján (lásd a mellékletet) azt mondhatjuk, hogy a stílust kivéve mindegyik mutató esetében elfogadható az objektivitás. A stílus kódolása nagyobb eltéréseket mutatott, ezek azonban nem véletlenszerủ, hanem szisztematikus eltérések voltak: a kutató szigorúbb volt a levél feladójával szemben, mint az asszisztens. Vagyis volt egyfajta szubjektivitás a kódolásban, mert ez a mutató nehezebben standardizálható.

16 Ehhez az imaplib és e-mail Python-csomagokat használtuk, melyek előnye az volt, hogy viszonylag hatékonyan lehetett az e-mailfiók tetszőleges mappájából szövegeket és ehhez tartozó fejlécadatokat kinyerni, mint például tárgy, dátum, feladó címe stb. 


\subsection{Automatizált szövegklasszifikáció}

Ahogy a bevezetőben említettük, a közszférabeli diszkrimináció mérésére irányuló kontrollált terepkísérletekre vonatkozó irodalomkutatásunkban egyetlen számítógépes válaszfeldolgozásra épülő kutatást találtunk (Giulietti-Tonin-Vlassopoulos 2015), ami azonban nem használta ki az automatizált szövegfeldolgozásban rejlő lehetőségeket. Ezért a diszkrimináció detektálására, kísérletként, a fent ismertetett regressziós modellek mellett egy innovatív, az e-mail-szövegek gépi tanulási megközelítésén alapuló megközelítést is kipróbáltunk. Arra voltunk kíváncsiak, hogy különböző, szövegek klasszifikálására alkalmas algoritmusokat (ezeket lásd később) menynyire lehet „megtanítani” arra, hogy csupán a válaszlevél szövege alapján helyesen sorolják be az e-mailben érdeklődőt roma/nem roma, illetve alacsony/magas státuszú kategóriákba (azaz mennyire taníthatók a fent definiált változók értékének megjóslására). Ha jól taníthatók az algoritmusok, az a diszkrimináció jelenlétének megerősítése, hiszen azt mutatja, hogy az e-mailek szövegében található olyan mintázat, ami a feladó vélt etnikumával vagy státuszával összefüggésbe hozható.

Ehhez a (felügyelt tanulásnak nevezett) eljáráshoz az algoritmus számára ismertté tettük az e-mailek kétharmada esetén, hogy roma/nem roma vagy alacsony/magas státuszú címkét visel-e a feladó. Az algoritmus célja az volt, hogy ebben a (tanulóhalmaznak nevezett) adatbázisban szövegmintázatokat keresve a számára ismeretlen címkéjû leveleket is be tudja illeszteni a kategóriarendszerbe, kizárólag a levél szövege alapján, minél nagyobb pontossággal. A modell klasszifikációs teljesítményének értékelése ezen felcímkézetlen egyharmad (az ún. teszthalmaz) alapján történt, itt vizsgáltuk meg, mekkora volt a tévedési arány; majd az eljárást megismételtük még kétszer, mindig másik harmadot választva teszthalmaznak (a felügyelt tanulás szövegelemzési felhasználásairól a társadalomkutatásban részletesebben lásd Németh-Katona-Kmetty (2020)).

A szövegklasszifikációban gyakran használt Elastic Net, Naive Bayes és XGBoost modelleket használtuk, a paraméterek hangolásával, R-beli implementálással, a caret és xgboost csomagok használatával. Ezek a modellek ún. szózsákmodellt használnak nyelvi modellként, azaz a szöveget az azt alkotó szavak összességeként kezelik, tekintet nélkül a szavak mondaton belüli helyzetére, sorrendjére. Bár leegyszerűsítő a modell, az algoritmusok bizonyos feladatokra jó teljesítménnyel használhatók (lásd NémethKatona-Kmetty 2020) - kérdésünk éppen az volt, hogy csak a szógyakoriság-mintázatok alapján látható-e különbség a feladó vélt etnikai/státuszbeli besorolása szerint. Az elemzéshez használt e-mailek adatbázisát előbb feldolgoztuk az automatizált szövegelemzésnél megszokott módon (preprocessing, lásd Németh-Katona-Kmetty 2020): a szöveget szavakra bontottuk, az írásjeleket töröltük, a szavakat szótövesítettük. Létrehoztunk néhány, az e-maileket jellemző potenciális magyarázó jellemzőt is: az egyes e-mailekben szereplő mondatok, szavak, különböző írásjelek (felkiáltójel, kérdőjel, veszsző stb.), emojik, hyperlinkek számát; valamint mértük az e-mailek lexikai diverzitását is. Továbbá, töröltünk bizonyos ritka kifejezéseket a szövegből, ilyenek voltak a telepü- 
lések vagy közös önkormányzati hivatalok nevei. Egy algoritmusvariánsként a szavak súlyozását az abszolút gyakoriságok mellett a term frequency inverse document.frequency (tf_idf) súlyozással is elvégeztük, ami a teljes adatbázisbeli előfordulást is figyelembe veszi egy adott szó adott e-mailben képviselt relevanciájának megállapításakor: kisebb súlyt ad neki, ha a szó a többi e-mailben is gyakran szerepel.

\subsection{Etikai megfontolások}

A terepkísérletek számos etikai kérdést vetnek fel, amelyek közül vitathatatlanul az egyik legkényesebb a tájékoztatást követő beleegyezés kérése a kísérleti alanyoktól (informed consent). Ebben a kutatásban, mint a legtöbb terepkísérletben, nem volt módunk az érintettek előzetes beleegyezésének elnyerésére. Ha elárultuk volna a hivatalnoknak, hogy kísérletben vesznek részt, akkor nem tudtuk volna valós élethelyzetben megfigyelni a viselkedésüket. A kutatás tervezésénél ezért a Journal of Experimental Political Science ajánlása alapján jártunk el (Morton-Tucker 2014). Az adattisztítás első lépésében anonimizáltuk az adatokat, és ezeket nem tettük közzé olyan bontásban, amiből következtetni lehetett volna a diszkrimináló hivatalnok kilétére. A kutatás célja ugyanis nem annak kiderítése volt, hogy egy adott településen diszkriminál-e a hivatalnok, hanem hogy általában véve van-e, és ha igen, milyen szintű a hivatali diszkrimináció. Szintén fontos szempont volt, hogy minimalizáljuk azt a „kárt” (amely elsősorban időveszteségként azonosítható), amelyet az írásos megkereséssel okoztunk. Az üzenet megfogalmazásánál ezért törekedtünk arra, hogy csak annyi kérdést tegyünk fel, amennyi a diszkrimináció finomabb megnyilvánulásának méréséhez feltétlenül szükséges, és ne terheljük le jobban a hivatalnokokat, mint egy átlagos ügyfél, akivel hétköznapi munkájuk során is találkoznának. Fontosnak tartottuk nemcsak etikai, hanem jogi szempontból is megalapozni a kutatást. Kutatási tervünket a CEU Etikai Bizottsága (2019) hagyta jóvá, és a Társaság a Szabadságjogokért (továbbiakban TASZ) véleményezte. Állásfoglalásuk szerint az álnéven előterjesztett adatigénylés nem jogszabályellenes, mivel az általunk feltett kérdések a magyar jogrendszerben közérdekű adatokra kérdeznek rá. „A feltett kérdést információszabadság-kérdésként azonosítjuk... A helyi általános tudnivalókról érdeklődő megkeresések a magyar jogrend szerint valójában közérdekű adatigénylések - függetlenül attól, hogy a megkeresés hivatkozik-e erre a tényre." (TASZ 2020)

\section{Eredmények}

\subsection{A származás és az etnicitás hatása a kapott válaszok jellemzőire}

A regressziós modellekben az etnicitás és a státusz változók szerepeltek prediktorként, így az etniticitás hatását a státusz hatásától megtisztítva tudtuk mérni. A kutatás keretében összesen 1269 önkormányzati hivatalnak küldtünk e-mailt, és ebből csupán 236 esetben (18,6 százalék) kaptunk feldolgozható választ. A kísérleti változó- 
kat együttesen vizsgálva a beérkező válaszok arányáról elmondható, hogy a legalacsonyabb válaszadási arányt az alacsony státuszú roma hangzású névvel rendelkező felhasználó esetében tapasztaltuk (15 százalék), míg a legmagasabb arányt a magas státuszú nem roma hangzású profil esetén (23 százalék). A nem roma hangzású alacsony státuszú 18, míg a roma hangzású magas státuszú tesztüzenetre az esetek 19 százalékában kaptunk választ. (1. ábra) A válaszarányok közötti eltérés statisztikai szignifikanciáját alább, más vizsgált kimenetekkel együtt tárgyaljuk.

1. ábra: Válaszadási arány etnikai hovatartozás és státusz szerint (95 százalékos konfidenciaintervallummal)

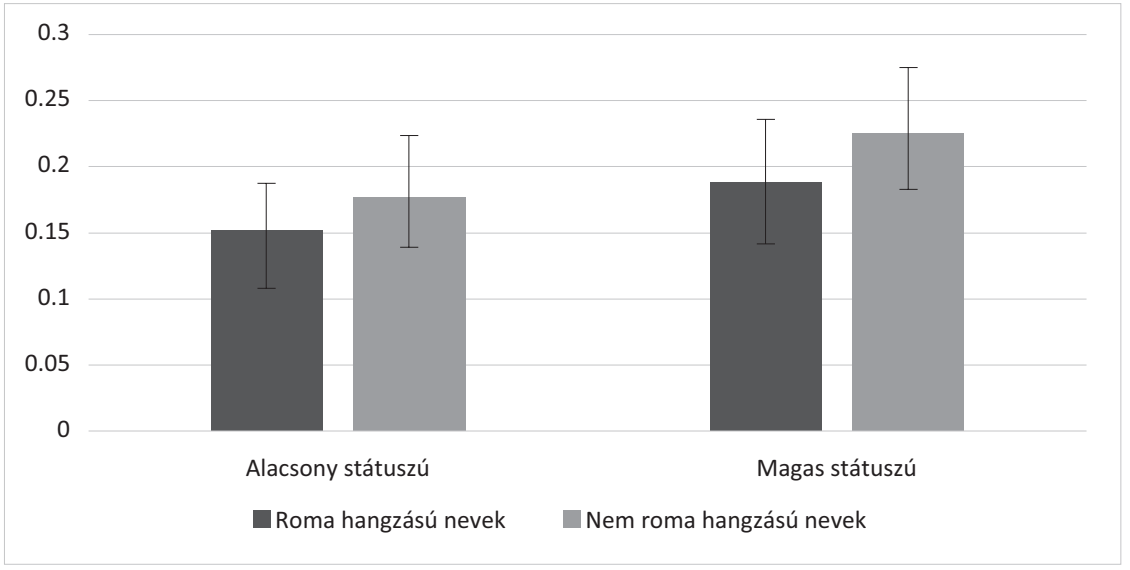

Megj.: mintanagyság a négy csoportra rendre: 316, 316, 318, 319.

A 3. táblázatban a kutatás fókuszában álló etnicitáshoz tartozó hatásbecslések mellett a státuszhoz tartozókat is közöljük (ezek az alacsony státusznak az etnicitástól megtisztított hatását mérik). Vizsgáltuk továbbá a státusz és az etnicitás interakcióját is, de az egyik esetben sem bizonyult szignifikánsnak, ezért a modellépítés során a takarékosság érdekében elhagytuk a modellekből. Más magyarázó változót (például a településeket jellemző változót) nem vontunk a modellbe, mert random módon történt a települések kísérleti csoportokba sorolása (a homogenitásvizsgálat sem mutatott ki köztük különbségeket), ezért e változók nem okozhattak zavaró hatást.

A válaszadás valószínűségét modellező logisztikus regressziós modell szerint az etnicitás szerint mért különbség nem szignifikáns (3. táblázat), azaz a kutatás kiinduló hipotézisét el kell vetnünk. Más szóval nincs statisztikai bizonyítékunk arra, hogy a roma felhasználók kisebb eséllyel kapnak választ a hivataltól. Ugyanakkor a 3. táblázat fontos tanulsága, hogy az alacsonynak vélt státusz szignifikánsan csökkenti a válaszadás esélyét: a stílusuk alapján alacsony státuszúnak percipiált feladók 25 százalékkal kisebb eséllyel kaptak választ. 
3. táblázat: Az etnicitás és a státusz hatása a vizsgált kimenetekre

\begin{tabular}{|c|c|c|c|c|}
\hline \multicolumn{2}{|c|}{ Vizsgált kimenet } & $\begin{array}{l}\text { vélt etnicitás } \\
\text { hatása } \\
\text { (roma vs. nem } \\
\text { roma) }\end{array}$ & $\begin{array}{c}\text { vélt státusz hatása } \\
\text { (alacsony vs. } \\
\text { magas) }\end{array}$ & $\mathrm{N}$ \\
\hline \multicolumn{2}{|c|}{ Érkezett-e válasz } & $0,81(0,61 ; 1,08)$ & $0,75 *(0,57 ; 1,00)$ & 1269 \\
\hline \multirow{3}{*}{$\begin{array}{l}\text { Tartalmi teljesség: } \\
\text { ajánlott-e a } \\
\text { válaszlevél... }\end{array}$} & ...parkolóhelyet & $0,52 *(0,27 ; 0,96)$ & $0,80(0,43 ; 1,50)$ & 224 \\
\hline & ...környékbeli látványosságot & $0,72(0,42 ; 1,24)$ & $\overline{0,37 * * *(0,21 ; 0,64)}$ & 227 \\
\hline & ...további információforrást & $0,89(0,51 ; 1,54)$ & $\begin{array}{c}0,32 * * *(0,18 ; \\
0,55) \\
\end{array}$ & 227 \\
\hline \multirow{2}{*}{ Hangnem/stílus } & $\begin{array}{c}\text { lekezelö, semleges, vagy kedves } \\
\text { hangnem }\end{array}$ & $0,96(0,59 ; 1,56)$ & $0,43 * *(0,26 ; 0,70)$ & 227 \\
\hline & $\begin{array}{c}\text { válaszüzenet hossza } \\
\text { karakterszámban }\end{array}$ & $-112(-283 ; 58)$ & $-91(-262 ; 80)$ & 216 \\
\hline
\end{tabular}

Hatásmutatók, zárójelben 95 százalékos konfidenciaintervallumukkal. Hatásmutató: esélyhányados, a válaszüzenet hoszszát kivéve, ahol átlagok különbsége.

$\mathrm{N}=$ mintaelemszám, szignifikanciaszintek: ${ }^{* * *}<0,001^{* *}<0,01^{*}<0,05$

A továbbiakban tartalmi szempontok szerint elemeztük a válaszüzeneteket. A tartalmi elemzésnél felmerül egy fontos módszertani kérdés, amire truncation-by-deathként vagy endogén önszelekcióként hivatkoznak a szakirodalomban (McConnell-Stuart-Devaney 2008). Ennek lényege, hogy ha egy randomizált kísérletben nem egyenlő a csoportokban kapott válaszarány, akkor a válaszokból generált egyéb elemzésekben (lásd tartalmi elemzés) nem vonhatunk le oksági következtetést, hiszen a csoportok már nem csak a kezelés tekintetében különböznek, hiszen történt egy önszelekció. Azt tudjuk csak mondani, hogy ha azt gondoljuk, hogy éppen a leginkább diszkriminatív emberek nem válaszolnak a romának vélt kérdezőnek, akkor a válaszadók részmintájában azok, akik romának válaszolnak, már kevésbé diszkriminatívak, mint azok, akik nem romának. Vagyis vélhetően alul fogjuk mérni a hatást a tartalmi elemzés során. E probléma kezelésének egyik módja, hogy a hiányzó adatokat a tartalmi elemzés során a legkedvezőtlenebb értékkel kódoljuk, például ha a válasz udvarias volta szerint kategorizáljuk az e-maileket, akkor a válaszhiány a legkevésbé udvarias kategóriába sorolódik (McConnell-Stuart-Devaney 2008: 170-172). Mivel ebben a kutatásban a válaszarány kapcsán nem mutatkozott statisztikailag szignifikáns etnikai hatás, feltételeztük, hogy az oksági következtetés feltételei a további, tartalmi elemzést célzó modellekben is tarthatóak voltak.

Az első tartalmi indikátor kapcsán azt vizsgáltuk, hogy a hivatal válaszlevelében ajánlott-e parkolóhelyet a településen vagy annak környékén. A 3. táblázat szerint a roma felhasználók feleakkora (0,52-szeres) eséllyel kapnak parkolóhely-ajánlatot a hivataltól, mint a nem roma felhasználók, amennyiben kontrollálunk a státuszra. Az alacsony státusz is csökkenti a parkolóajánlás esélyét, de ez a különbség nem szignifikáns.

A következő vizsgált tartalmi jellemző azt rögzítette, hogy a hivatal ajánlott-e bármilyen látványosságot a településen vagy annak környékén. A 3. táblázat eredményei szerint ugyan mérhető a romák hátránya e tekintetben, de a különbség statisztika- 
ilag nem szignifikáns. Ugyanakkor a státusz hatása szignifikáns és nagyon erős: az alacsony státusz önmagában (tehát függetlenül a roma etnicitástól) egyharmadára csökkenti a látványosságajánlás esélyét.

Az utolsó vizsgált tartalmi mutató a válasz teljességére vonatkozott - ajánlott-e a válaszadó bármilyen forrást, ahol bővebb információ volt szerezhető a település történetéről. Eredményeink szerint ugyan mutatkozott némi hátrány a romák szempontjából e tekintetben, de az eltérés statisztikailag nem szignifikáns. A státusz hatása azonban ebben az esetben is szignifikáns és nagyon erős: az alacsony státuszúak esélye az információforrás megkapására csupán egyharmada a magas státuszúéknak. Tehát a tartalmi teljességet mérő három indikátor közül egy esetben az etnicitás (roma) a másik két esetben a társadalmi státusz mutató (alacsony státusz) határozta meg a kapott válasz minőségét.

A válaszok hangnemével (lekezelő, semleges vagy kedves) mért kezelési hatást ordinális logisztikus regresszióval (ún. proportional odds modellel) vizsgáltuk, ahol a kimenetnek három lehetséges kategóriája volt. A 3. táblázat alapján van ugyan némi különbség a romák kárára, de az eltérés nem szignifikáns, azaz nem állíthatjuk, hogy a roma felhasználók kisebb eséllyel kapnak kedvesebb választ a hivataltól, mint a nem roma felhasználók. A státusz hatása ugyanakkor itt szignifikáns, az alacsony vélt státusz erősen csökkenti a kedves válasz esélyét (az esélyhányados 0,43).

A válaszüzenetek átlagos hossza 622 karakter volt, és a 3. táblázatból leolvasható, hogy a roma felhasználók átlagosan lényegesen (átlagosan 112 karakterrel) rövidebb választ kaptak, mint az azonos státuszú nem roma felhasználók, ám ez a különbség sem volt szignifikáns. Tehát nincs elég bizonyítékunk arra, hogy a roma felhasználók rövidebb üzenetet kapnak a hivataltól, mint a nem roma felhasználók. A státusz esetében hasonló a helyzet: az alacsony státuszúak (átlagosan 91 karakterrel) rövidebb választ kaptak, de ez a különbség sem szignifikáns.

\section{Gépi tanulásos klasszifikáció}

Gépi tanulásra épülő klasszifikációs modelljeink esetében a legfontosabb kérdés az, hogy a modelleknek sikerült-e valóban „tanulniuk”, azaz találtak-e olyan szövegmintázatokat, amelyek alapján a válaszokat helyesen tudják klasszifikálni az érdeklődő vélt etnicitása, illetve státusza szerint. A klasszifikációs teljesítményt több dimenzió mentén értékeltük. A helyes besorolások arányán túl külön vizsgáltuk a kísérleti kezelés által kijelölt csoportokon belüli helyes besorolásarányt is. ${ }^{17}$ Használtuk továbbá a gépi tanulásban nagyon elterjedt AUC mutatót. ${ }^{18}$ Értékeléséhez tudni kell, hogy az AUC 0,5 és 1 között vehet fel értéket. Minél nagyobb az értéke, annál jobb a predikció;

17 Lásd: a COVID-tesztek múködését nemcsak a helyes besorolások összesített aránya szerint értékelik, hanem külön vizsgálják a valódi betegeken belüli tesztpozitív arányt (szenzitivitás), illetve az egészségeseken belüli tesztnegatív arányt (specificitás). A klasszifikációs modellek a biostatisztikában születtek diagnosztikus tesztekként, ezért nómenklatúrájuk is onnét lehet ismerős. Részletesebben lásd Reiczigel Jenő könnyen olvasható kitűnő biostatisztika-jegyzetét (2005).

18 Az AUC (area under the curve) elnevezése onnan ered, hogy az ún. ROC-görbe alatti terület nagyságaként adódik (lásd Reiczigel, 2005). Mivel a klasszifikáció tkp. valamely pontozásra épülve sorolja adott küszöb fölé esőket roma vagy alacsony státuszú kategóriákba, az AUC egyetlen számba sürítve méri a klasszifikációs modell különböző küszöbök mellett mért teljesítményét. 
0,5 körüli AUC-értéke egy minden informativitást nélkülöző, random módon klasszifikáló modellnek van.

Klasszikus magyarázó modell építése esetén az illeszkedés jósága (goodness of fit) az a mutató, amely a modell érvényességét jellemzi. Predikciós modell esetén a fő kérdés az, hogy modellünk egy másik mintán is hasonlóan jó teljesítményt lenne-e képes mutatni. Felléphet ugyanis a túlillesztés (overfitting) esete, amikor a modell a mintát írja le a benne lévő random zajjal együtt, és nem a tényleges mögöttes adatgeneráló mechanizmust - a túlillesztés következményeként a modell rosszul teljesítene egy külső, független mintán. Ezért modellünket mi sem egyszerűen az adott mintán értékeltük, hanem úgynevezett keresztvalidációt (cross-validation) alkalmaztunk, erről bővebben lásd Németh-Katona-Kmetty írását (2020). ${ }^{19}$

Eredményeink szerint a válasz-e-mail szövege alapján a feladó vélt etnicitása roszszul prediktálható: az AUC-mutató értéke a legjobb modell esetén is csak 0,60 körül volt - ami hatékony predikcióra ugyan nem teszi alkalmassá a modellt, de a random klasszifikációt jóval meghaladó teljesítményt mutat. Ugyanakkor a státusz sokkal jobban megjósolható: a legjobban teljesítő modell (XGBoost) ${ }^{20}$ a válaszmailek 73 százalékát helyesen sorolta be a feladó státusza szerint. Részletesebben: a magas státuszú stílusban íródott levélre írt válaszok 70 százalékát (szenzitivitás), illetve az alacsony státuszú stílusban íródott levélre írt válaszok 77 százalékát (specificitás) jó helyre sorolta. A modell AUC-mutatója 76 százalékos, ami a gyakorlatban használt „hüvelykujjszabályok" szerint elfogadható teljesítménynek számít.

A gépi tanulásos klasszifikációs kísérlet eredménye részben megfelel a regressziós modellek eredményeinek, melyek szintén azt mutatták, hogy a státusz szerinti diszkrimináció sokkal világosabban kimutatható, mint az etnicitás szerinti. Ugyanakkor azt is mutatják a kísérlet eredményei, hogy az automatizált szövegelemzésnek a humán értelemzéshez képest nyilvánvaló erős korlátai vannak (a humán értelemzésre mint függő változóra épülő regressziós modellek mutattak azért etnikai diszkriminációt, bár ez a hatás csak egy indikátor esetén volt szignifikáns). Nem is ez a nyilvánvaló gép-ember különbség érdemel figyelmet, hanem az, hogy az algoritmusaink által használt, egyszerü nyelvi modell mellett is kimutatható, hogy a közhivatalnokok különbséget tesznek ügyfeleik vélt státusza szerint.

\section{Diszkusszió}

Kutatásunk legfontosabb tanulsága, hogy a nemzetközi eredményekkel összhangban, míg a válaszok arányában csekély, addig a válaszok tartalmi jellemzőiben jelentősebb eltéréseket találtunk az elsődleges kísérleti változó, az etnicitás mentén. A roma

19 Három részre osztottuk a mintát, az egyik harmad kihagyásával kapott kétharmadon illesztettük a modellt (tanulóhalmaz), majd a modell teljesítményét a kihagyott harmadon (validációs halmaz) értékeltük. Miután ugyanezt elvégeztük mindhárom harmadon, a modell predikciós hibáját a három validációs hiba átlagaként definiáltuk. A keresztvalidáció alkalmazása egyúttal a viszonylag alacsony elemszám (236 válasz-e-mail) hatását is számszerüsíti: ha túl alacsony a minta, a modell várhatóan nem mutat jó predikciós teljesítményt a validációs halmazon.

20 Az XGBoost a döntési fákat általánosító modell. A legjobb modell paraméterbeállításai a következők voltak: eta = .5, max_depth $=6$, min_child_weight $=1$, gamma $=5$, optimal_trees $=8, n \_$rounds $=100$. 
hangzású névvel rendelkező felhasználók esetében ugyan valamelyest alacsonyabb volt a válaszarány (17 vs. 20 százalék), de ez az eltérés statisztikailag nem jelentôs. A státusz hatása ugyanakkor tetten érhető volt a válaszadási arányokban, az alacsonynak vélt státusz ugyanis szignifikánsan csökkenti a válaszadás esélyét, ami részben alátámasztja a statisztikai diszkrimináció érvényesülését az önkormányzati ügyintézés során. (Mivel feltételezhetjük, hogy az ügyintéző azt gondolhatja, hogy nagyobb munkaidő-ráfordítással jár az alacsony státuszú ügyfél tájékoztatása és segítése, nem segíti ugyanolyan mértékben.)

A válasz minőségét mérő indikátorok közül mindössze egy esetben bizonyult az etnicitás (roma) meghatározónak: a parkolóhellyel kapcsolatos kérdés esetében. Ugyanakkor a tartalmi teljességet mérő három indikátor közül kettő esetében, illetve a válasz hangnemének kedvességét tekintve is szignifikáns és erős volt a társadalmi státusz mutató hatása. Tehát a kutatásunk nem várt eredménye, a státusz etnicitástól függetlenül - kimutatható, erős hatása: az ügyintéző által percipiált magas státusz növelte annak az esélyét, hogy tartalmilag jó minőségú és kedves választ kap a kérdező, az alacsonynak vélt státusz pedig erősen csökkentette a kedves és teljes válasz kapásának esélyét.

A válasz-e-mailek automatizált szövegelemzése a fentiekkel összhangban lévő eredményeket hozott: a gépi tanulás segítségével kimutatható volt, hogy a közhivatalnokok különbséget tesznek ügyfeleik vélt státusza szerint. Algoritmusaink kevésbé találtak hasonló különbséget a vélt etnicitás vonatkozásában. Ebből arra következtethetünk, hogy a státusz szerinti különbségtétel inkább explicit, míg az etnikai diszkrimináció nyelvi megformálását tekintve (is) látensebb jegyekre támaszkodhat.

A kiinduló hipotézisünk tekintetében kutatásunk eredménye alapvetően megegyezik a korábban publikált kutatások nagy részével, amelyek nem találtak kellő bizonyítékot arra, hogy a kisebbségi ügyfelek kisebb eséllyel kapnak válaszüzenetet a hivatalnokról. Plauzibilisnek tűnik Hemker és Rink (2017) állítása, miszerint az etnikai alapú hivatali diszkrimináció finomabb módokon nyilvánul meg, mint az ügyfél teljes mértékü figyelmen kívül hagyása, és egy jól megtervezett terepkísérleti dizájn kialakítása során ezeket is számításba kell venni. Eredményeink összhangban vannak a Bartoš és szerzőtársai (2016) által azonosított a döntéshozók eltérő figyelmében megnyilvánuló diszkriminációs viselkedési mechanizmusokkal, amit adataink az önkormányzati ügyintézés során is alátámasztottak.

Jelen kutatás másik fontos tanulsága pedig az, hogy a teljes válaszarány (19 százalék) a magyar önkormányzatok körében jóval alacsonyabb volt, mint a hasonló területen végzett nemzetközi terepkísérleteké. Ennek több lehetséges magyarázata is lehet. Az egyik kézenfekvő magyarázat, hogy a válaszarányt jelentősen befolyásolhatja, hogy az adott országban a hivatali szabályzat megköveteli-e az alkalmazottaktól, hogy válaszoljanak minden lakossági e-mailre. Az európai uniós országok többségében létezik ugyan a közérdekủ adatigénylésre vonatkozó törvény, mégis nagy eltérések tapasztalhatóak az önkormányzatok válaszadási hajlandóságában. Az általunk meg- 
ismert országok közül Svédországban rögzítették a legmagasabb, 90 százalék feletti válaszarányt (Adman-Jansson, 2017, és Ahmed-Hammarstedt 2019.). Magyarországon is törvény rendelkezik e kérdésről, mely azt is szabályozza, hogy a közfeladatot ellátó szervnek kötelessége legfeljebb 15 napon belül megválaszolni az írásban vagy elektronikus úton benyújtott kérdést. A TASZ állásfoglalása szerint az általunk feltett kérdések egyértelműen közérdekü adatigénylésnek tekinthetők, amit az információs önrendelkezési jogról és az információszabadságról szóló 2011. évi CXII. törvény értelmében bárki benyújthat, akár névvel, akár anonim módon az önkormányzatoknak mint közfeladatot ellátó szervnek. A törvényi kötelezettség ellenére az ügyintézők többsége számára nem egyértelmű a válaszadási kötelezettség. ${ }^{21}$

Az alacsony válaszarány másik oka az lehet, hogy mivel kutatásunk tervezett mintája a hazai önkormányzati hivatalokat teljeskörűen lefedte, nagyon sok kistelepülésnek is küldtünk e-mailt. Ezzel szemben a legtöbb külföldi kutatásban jellemzően csak a városokat, vagy azokon belül is csak a néhány tízezer főt meghaladó településeket vették be a mintakeretbe (például Grohs-Adam-Knill 2016). ${ }^{22}$

Végül, sok szempontból nem volt ideális a terepmunka időzítése sem: a koronavírus-válság kapcsán meghozott 2020. márciusi korlátozó intézkedéseket közvetlenül megelőző hetekben kiküldött kérdéseinkre feltehetőleg azért is érkezett kevés válasz, mert az ügyintézőket munkájukban akadályozta a lezárást megelőző nagy fokú egyéni és munkahelyi bizonytalanság. Ugyanakkor azt gondoljuk, hogy mivel ez a faktor nem állt kapcsolatban a kezelési változókkal, feltehetőleg nem hozott szisztematikus torzítást eredményeinkbe, viszont a válaszadási hajlandóságot érdemben csökkenthette.

Mivel a jelen kísérlet egy nagyobb kutatás pilotjának tekinthető, fontosnak tartjuk mérésünket érvényesség szempontjából értékelni. Belső validitás szempontjából a terepkísérletek általában jól működnek, és ez a kísérlet is feltehetőleg erős (egy kérdőíves attitűd vizsgálathoz képest), a gondosan felépített dizájn, a megfelelő előkészítés (interjúk) és korábbi kutatási tapasztalatok felhasználásának köszönhetően. A kísérleti ingereket, a kérelmező etnicitását (nevek) és státuszát korábbi kutatások során már részben kipróbált formában használtuk. Belső validitás szempontjából a mérőeszköz gyengeségének tekinthető ugyanakkor, hogy az e-mail tárgya egy nem kifejezetten hétköznapi kérés volt: mivel Magyarországon feltehetőleg ritkán érdeklődnek lakókocsi-parkolással kapcsolatban az önkormányzatoknál, nem zárhatjuk ki, hogy ez a kevéssé „életszerü” kérdésfelvetés a visszaérkező válaszok arányát és minőségét is befolyásolhatta.

Külső validitás szempontjából azonban némileg korlátozottnak mondhatóak az eredmények. Mintavételi szempontból nagy fokú az általánosíthatóság, mivel teljes

21 Az előkutatásunk során az egyik interjúalany diszkréten úgy fogalmazott ebben a kérdésben, hogy a hivatalnak „illö lenne válaszolnia” minden e-mailre, azonban az e-mail nem minősül „hivatalos iratnak" (szemben például az e-önkormányzati ügyintézéssel). Interjúink alapján elmondható, hogy a helyi önkormányzatok belső szabályrendszere különböző, a nagyobb fővárosi önkormányzatoknál például kiszignálják a megfelelő területek számára az e-mailes megkereséseket.

22 Amennyiben a kutatást a városokra szűkítenénk, akkor a teljes válaszarány 19 százalékról 35 százalékra ra nőne, a mintakeret pedig nagyjából egyötödére, 1270-ről 278-ra csökkenne. 
populációból indult ki az adatfelvétel (egy tucat önkormányzati hivatal kivételével mind bekerült a mintába). Ugyanakkor egyrészt nem volt teljes kontrollunk afelett, hogy ki válaszol a kérdésekre. Néha a központi kapcsolattartó, néha azonban más funkciójú személy (polgármester, jegyző vagy különböző osztályok alkalmazottai). Ez a probléma azonban orvosolható azáltal, hogy az elemzési egységnek az önkormányzati hivatalt tekintjük, nem pedig a válaszadó személyt. Végül az a választás, hogy az önkormányzati tisztviselőkkel való kommunikációban egyedül az e-mailezésre szorítkoztunk, szintén felvet validitási problémákat. Eredményeink a hivatali érintkezésnek csak egy nagyon kis szeletére, az elektronikus kommunikációra általánosíthatók.

Szakértőink ${ }^{23}$ szerint ugyanakkor 2020 tavaszán fontos változást jelentett, hogy a települési önkormányzatok jó része a legtöbb területen szüneteltette a személyes ügyfélfogadást, és átálltak az online, illetve telefonos ügyintézésre (mely lehetőségekre a hivatalok honlapjain és Facebook-oldalain is felhívták a polgárok figyelmét).

Utólag egyetértünk cikkünk anonim lektorának azzal a megjegyzésével, hogy a kutatási dizájn szempontjából nem volt szerencsés döntés az, hogy míg a magas státuszú nevek e-mail-címében szerepelt egy-egy kétjegyú szám (83, illetve 90), amelyek utalhattak a levélíró életkorára, az alacsony státuszú levelekben nem szerepelt szám. Döntésünk oka egyszerúen az volt, hogy az alacsony státuszú e-mail-címekben, a státusz hatásának erősítését célozva becéző alakokat használtunk, míg a magas státuszúaknál minél semlegesebb e-mail-címet próbáltunk létrehozni. Bár nem gondoljuk azt, hogy a számok által nem szándékoltan bevitt életkori utalás komoly hatással lehetett az ügyintézők válaszaira, fontosnak tartjuk megemlíteni a jövőbeli kutatások precízebb előkészítése szempontjából.

Jelen kutatás tanulságaira építve 2020 nyarán egy több hullámban megvalósuló tesztsorozatot végeztünk, amelybe aktívan bekapcsolódott a TASZ is. A kutatássorozatunk policy relevanciája szintén jelentős. Az EU tagállamai romákkal kapcsolatos kutatásainak, inklúziós projektjeinek és azok monitorozásának fontos hiányossága, hogy a roma diszkrimináció konkrét mértékéről nagyon keveset tudhatunk meg belőlük. Kutatássorozatunk ezt a hiányosságot is pótolni igyekezett azáltal, hogy első becslést adtunk a roma és alacsony társadalmi státuszú polgárokkal szembeni diszkrimináció mértékére a magyar közhivatalokkal való érintkezés egy szegmensében, az elektronikus kommunikáció terén.

\section{Discrimination at local governments? - Results of an online field experiment}

Abstract: In the beginning of 2020, we conducted a controlled field experiment with the goal of evaluating whether local governments in Hungary practice overt or latent forms of discrimination while dealing with citizens online. We sent out a total of 1270 emails posing either as high or low status Roma citizens with practical questions. Whereas those in the experimental group received emails from citizens with Roma sounding names, those in the control group received emails from citizens with non-Roma sounding names. In harmony with the findings of studies done in other countries, there was no significant difference in the

23 A projekt során folyamatosan együttműködtünk a TASZ jogászaival, illetve az egyik budapesti önkormányzat hivatalvezetőjével, akik jogi és gyakorlati (konkrét ügyintézési) kérdésekben segítettek eligazodni. Segítő közremúködésüket ezúton is köszönjük. 
number of answers the two groups received. However, with regards to the style and content of the answers, we found a number of significant differences affected by the primary experimental variable, i.e. ethnicity. Unexpectedly, social status-our secondary experimental variable-turned out to be statistically affecting both the number of received answers, as well as the style and content of the answers. This result was also confirmed by machine learning text analysis. Therefore, we have found that local government employees discriminate mostly between citizens based on their perceived social status; and that they discriminate only slightly between citizens based on their assumed ethnicity. When comparing the effect of ethnicity and social status, it is important to emphasize that ethnicity only had a slight effect on the linguistic style of the answers as detectable by human coding; social status, on the other hand, affected both whether a citizen's email was answered at all, as well as the linguistic style of the answers as detectable by machine learning text analysis. Our results are in line with the model of attention discrimination developed by Bartoš and his colleagues in 2016.

Keywords: field experiments, discrimination, social status, local governments

\section{Irodalom}

Adman, P. - Jansson, H. (2017): A field experiment on ethnic discrimination among local Swedish public officials. Local Government Studies, 43 (1): 44-63. https://doi.org/10.1080/03003930.2016.1244052

Agresti, A. (2007): Introduction to Categorical Data Analysis. Hoboken, New Jersey, Canda: John Wiley \& Sons.

Ahmed, A. - Hammarstedt, M. (2019): Ethnic discrimination in contacts with public authorities: A correspondence test among Swedish municipalities. Applied Economics Letters, 1-4. https://doi.org/10.1080/13504851.2019.1683141

Arrow, K. J. (1973): The Theory of Discrimination. In Ashenfelter O. - Rees A. (eds.): Discrimination in Labor Markets, Princeton. New Jersey: Princeton University Press.

Arrow, K. J. (1998): What has Economics to Say About Racial Discrimination? Journal of Economic Perspectives, 12 (2): 91-100.

Bárdits A. - Kádár A. K. - Novoszádek N. - Simonovits B. - Szegő D. - Vincze D. (2014): Utolsók az egyenlők között. Sérülékeny csoportok törvény előtti egyenlösége a büntető igazságszolgáltatásban. Budapest: Magyar Helsinki Bizottság.

Bartoš, V. - Bauer, M. - Chytilová, J. - Matějka, F. (2016). Attention Discrimination: Theory and Field Experiments with Monitoring Information Acquisition. American Economic Review, 106(6), 1437-1475. https://doi.org/10.1257/aer.20140571

Becker, G. S. (1971): The Economics of Discrimination. Chicago: The University of Chicago Press.

Bóday P. (2019): Magyarország közigazgatási helynévkönyve. Budapest: KSH. https://www.ksh.hu/docs/hun/hnk/hnk_2019.pdf

Burns, M. K. (2014): How to establish interrater reliability. Nursing2020, 44 (10): 56-58. https://doi.org/10.1097/01.NURSE.0000453705.41413.c6

Centre for Policy Studies, Central European University (2018): A synthesis report on implementation of national Roma integration strategies in Bulgaria, Czech Republic, 
Hungary, Romania and Slovakia. Brussels: Centre for Policy Studies, Central European University. https://cps.ceu.edu/sites/cps.ceu.edu/files/attachment/basicpage/3034/ rcm-civil-society-monitoring-report-1-synthesis-cluster-1-2017-eprint-fin.pdf

Cui, R. - Li, J. - Zhang, D. (2017): Discrimination with Incomplete Information in the Sharing Economy: Evidence from Field Experiments on Airbnb. Cambridge: Harvard Business School, 1-35.

Daróczi G. - Horváth B. L. - Leitheiser F. - Mészáros G. - Ország D. - Ozsvári I. - Vörös K. - Simonovits B. (2017): Diszkriminációtesztelés az Oszkár telekocsi rendszerben [kézirat]. Budapest: Eötvös Loránd Tudományegyetem, Kisebbségpolitika MA.

Distelhorst, G. - Hou, Y. (2014): Ingroup Bias in Official Behavior: A National Field Experiment in China. Quarterly Journal of Political Science, 9 (2): 203-230. https://doi.org/10.1561/100.00013110

Einstein, K. L. - Glick, D. M. (2017): Does Race Affect Access to Government Services? An Experiment Exploring Street-Level Bureaucrats and Access to Public Housing. American Journal of Political Science, 61 (1): 100-116. https://doi.org/10.1111/ajps.12252

European Commission (2019): Discrimination in the European Union. Special Eurobarometer 493. Brussels: European Commision. https://doi.org/10.2838/5155.

European Roma Rights Centre (2007): The Glass Box. Exclusion of Roma from Employment. Brussels: European Roma Rights Centre. http://www.errc.org/uploads/upload_en/file/02/14/m00000214.pdf

European Union Agency for Fundamental Rights (2016): EU-MIDIS II: Second European Union Minorities and Discrimination Survey. Roma - Selected findings. Luxembourg: European Union Agency for Fundamental Rights, 52.

Giulietti, C. - Tonin, M. - Vlassopoulos, M. (2015): Racial Discrimination in Local Public Services: A Field Experiment in the US (CESifo Working Paper, No. 5537). Center for Economic Studies and Ifo Institute (CESifo).

Gneezy, U. - List, J. - Prince, M. K. (2012): Toward an Understanding of Why People Discriminate: Evidence from a Series of Natural Field Experiments. NBER Working Paper, 17855: February. http://www.nber.org/papers/w17855 (letöltve: 2012. 06. 05.) Grohs, S. - Adam, C. - Knill, C. (2016): Are Some Citizens More Equal than Others? Evidence from a Field Experiment. Public Administration Review, 76 (1): 155-164. https://doi.org/10.1111/puar.12439

Hemker, J. - Rink, A. (2017): Multiple Dimensions of Bureaucratic Discrimination: Evidence from German Welfare Offices: Bureaucratic discrimination. American Journal of Political Science, 61 (4): 786-803. https://doi.org/10.1111/ajps.12312

Hidas, S. - Machlica, G. - Žúdel, B. (2014): Unemployment in Slovakia. Financial Policy Institute, Ministry of Finance of the Slovak Republic.

https://www.mfsr.sk/sk/financie/institut-financnej-politiky/publikacie-ifp/ ekonomicke-analyzy/30-unemployment-slovakia-november-2014.html https://helsinki.hu/wp-content/uploads/MHB_STEPSS_HU.pdf 
Jilke, S. - Van Dooren, W. - Rys, S. (2018): Discrimination and Administrative Burden in Public Service Markets: Does a Public-Private Difference Exist? Journal of Public Administration Research and Theory, 28 (3): 423-439.

https://doi.org/10.1093/jopart/muy009

Kaas, L. - Manger, C. (2010): Ethnic Discrimination in Germany's LabourMarket: A Field Experiment. IZA Discussion papers, 4741: February.

http://ftp.iza.org/dp4741.pdf

Kádár A. K. - Körner J. - Moldova Zs. - Tóth B. (2008): Szigorúan Ellenőrzött Iratok. A magyar igazoltatási gyakorlat hatékonyságáról és etnikai aspektusairól. Budapest: Magyar Helsinki Bizottság.

Koltai, J. A. - Sik, E. - Simonovits, B. (2015): A kvanti-kvali áldilemmán túl. Szociológiai Szemle, 25 (2): 32-49.

Kormany.hu (é. n.): Megjelent az Önkormányzati Tudástár - Önkormányzati Címtár 2015. Belügyminisztérium.

https://www.kormany.hu/hu/belugyminiszterium/onkormanyzati-allamtitkarsag/ hirek/megjelent-az-onkormanyzati-tudastar-onkormanyzati-cimtar-2015 (Letöltve: 2020. 04. 24.)

Közigazgatási és Elektronikus Közszolgáltatások Központi Hivatala (2019): Születési családnevek. (XLSX)

Loury, G. C. (2006): A faji egyenlōtlenségek anatómiája. Budapest: Nemzeti Tankönyvkiadó, Közgazdasági Kiskönyvtár.

Lovász A. - Telegdy Á. (2009): Munkapiaci diszkrimináció-típusok, mérési problémák, empirikus megoldások. In Fazekas K. - Lovász A. - Telegdy Á. (szerk.): Munkaerőpiaci Tükör. Budapest: MTA Közgazdaságtudományi Intézet Országos Foglalkoztatási Közalapítvány, 46-66.

Magyarnevek.hu (é. n.): Magyar Keresztnevek Tára.

http://magyarnevek.hu/nevek/utonevstatisztika (Letöltve: 2020. 04. 24.)

Mandiner.hu (2012. július 13): A Jobbik szerint elfogadhatatlan a pozitív diszkrimináció. https://mandiner.hu/cikk/20120713_jobbik_pozitiv_diszkriminacio_csak_a_ kulturaban_kell

McConnell, S. - Stuart, E. A. - Devaney, B. (2008): The Truncation-by-Death Problem: What To Do in an Experimental Evaluation When the Outcome Is Not Always Defined. Evaluation Review, 32 (2): 157-186.

https://doi.org/10.1177/0193841X07309115

Miller, J. - Gounev, P. - Pap, A. L. - Wagman, D. - Balogi, A. - Bezlov, T. - Simonovits, B. - Vargha, L. (2008): Racism and police stops: adapting US and British debates to continental Europe. European Journal of Criminology, 5 (2): 161-191.

Morton, R. B. - Tucker, J. A. (2014): Experiments, Journals, and Ethics. Journal of Experimental Political Science, 1 (2): 99-103. https://doi.org/10.1017/xps.2014.23

Neményi M. - Ferencz Z. - Laki I. - Ságvári B. - Takács J. - Tardos K. - Tibori T. (2013): Az egyenlő bánásmóddal kapcsolatos jogtudatosság növekedésének elemzése 
2010-2013 között - fókuszban a nök, romák, a fogyatékos, és az LMBT emberek. Budapest: Egyenlő Bánásmód Hatóság, 96. https://www.egyenlobanasmod.hu/sites/ default/files/kiadvany/EBH_7_kiadvany_Final_20130619.pdf

Neményi M. - Ságvári B. - Tardos K. (2019): A diszkrimináció személyes és társadalmi észlelése és az egyenlő bánásmóddal kapcsolatos jogtudatosság. Budapest: Egyenlő Bánásmód Hatóság. https://www.egyenlobanasmod.hu/sites/default/files/ kiadvany/EBH_2019_kutatas_web_online_sm.pdf

Németh R. - Katona E. R. - Kmetty Z. (2020): Az automatizált szövegelemzés perspektívája a társadalomtudományokban. Szociológiai Szemle, 30 (1): 44-62.

Pager, D. - Shepherd, H. (2008): The sociology of discrimination: Racial discrimination in employment, housing, credit, and consumer markets. Annual Review of Sociology, 34: 181-209. https://doi.org/10.1146/annurev.soc.33.040406.131740

Pálosi É. - Sik E. - Simonovits B. (2007): Diszkrimináció a plázában. Szociológiai Szemle, 3-4, 135-149.

Phelps, E. S. (1972): The Statistical Theory of Racism and Sexism. American Economic Review, 62 (4): 659-61.

Reiczigel J. (2005): Válogatott fejezetek a biostatisztikából. Budapest: SZIE ÁOTK. http://www.univet.hu/users/jreiczig/valfej/val-fej-jegyzet-2005-02-05.pdf

Sik E. - Simonovits B. (2008): Egyenlő bánásmód és diszkrimináció. In Kolosi T. Tóth I. Gy. (szerk.): Társadalmi Riport. 2008. Budapest: Tárki, 363-386.

http://www.tarsadalomkutatas.hu/kkk.php?TPUBL-A-822/publikaciok/tpubl_a_822.pdf STHDA.com (é.n): Linear Regression Assumptions and Diagnostics in R: Essentials. http://www.sthda.com/english/articles/39-regression-model-diagnostics/161linear-regression-assumptions-and-diagnostics-in-r-essentials/

(Letöltve: 2020. 04. 24.)

TASZ (2020. november 16.): Állásfoglalás közigazgatási szervnek küldött kutatói kérdés jogszerúségéről. November 16. https://tasz.hu/cikkek/allasfoglalaskozigazgatasi-szervnek-kuldott-kutatoi-kerdes-jogszerusegerol

UCLA.edu (é. n.): FAQ: How do I interpret odds ratios in logistic regression? 4https:// stats.idre.ucla.edu/other/mult-pkg/faq/general/faq-how-do-i-interpret-oddsratios-in-logistic-regression/ (Letöltve: 2020. 04. 24.)

UCLA.edu (é. n.): Ordinal Logistic Regression | R Data Analysis Examples. https://stats. idre.ucla.edu/r/dae/ordinal-logistic-regression/ (Letöltve: 2020. 04. 24.)

Valli, V. - Stahl, F. - Feit, E. M. (2017): Field Experiments. In C. Homburg, M. Klarmann, A. Vomberg (eds.): Handbook of Market Research. Springer International Publishing 1-29. https://doi.org/10.1007/978-3-319-05542-8_3-1

Weichselbaumer, D. (2016): Discrimination against Female Migrants Wearing Headscarves. IZA Discussion papers, 10217: September.

Az online melléklet az alábbi linken érhető el:

https://szociologia.hu/uploads/csomor_melleklet.pdf 